kårlighed danner dekorativ baggrund. Alt forbliver - sort og hvidt.

Den annoncerede bearbejdning på Tiderne Skifter skal ifølge forfatteren blive til en mere alment tilgængelig bog uden den akademiske omstændelighed, som man ikke kommer uden om $i$ en afhandling. De mest oplagte steder lover Sharma at perspektivere de amerikanske forhold til smørhullet Danmark. Selv om forskellene skærer i øjnene, kommer hun næppe uden om at behandle den inspiration fra amerikansk retspolitik, der med terrorloven af 2002 som paradigmatisk eksempel også har sat sit præg på danske fængselsforhold. Devika Sharma kan også i Danmark finde fængselsbilleder, der, som hun udtrykker det i afhandlingens slutreplik, tager "del i den politiske kamp, som vi skylder det amerikanske fængsel." (s. 234)

Henrik Borup Nielsen

Fangen som forsogs-menneske

Espen Schaanning: Menneskelaboratoriet. Botsfengslets historie. Scandinavian

Academic Press, Oslo 2007, 636 sider, 398 Nkr.

Man skal ikke lade sig vildlede af bogens titel: Espen Schaannings erklærede mål er intet mindre end at skildre "norsk straffetenkning, fengselspraksis og kriminologi på bakgrunn av parallelle prosesser i Europa og USA ... og forbindelseslinjene mellom disse vitenfeltene i Norge" (s. 13) fra star- ten af 1800 -tallet indtil 1940 . For at kunne håndtere dette $\mathrm{i}$ tid og indhold omfangsrige emne fokuserer idéhistorikeren Schaanning på vidensproduktionen i Botsfengslet, som indtog en central, om end skiftende position indenfor det norske straffevæsen.

De første fire kapitler skildrer opkomsten af fængselsreformdiskursen og det moderne norske fængselsvæsen med særlig hensyn til oprettelsen af og praksis i landets eneste cellefængsel, Botsfengslet, og kan på den måde sammenlignes med andre studier som Roddy Nilssons og Peter Scharff Smiths studier om hhv. Sverige og Danmark. Kapitel 1 præsenterer de velkendte idehistoriske forudsætninger med Beccaria, Howard osv., men fremhæver særligt de parallelle udviklinger i fængslerne og asylerne. På denne baggrund knyttes i kapitel 2 lægen Frederik Holsts afhandling ("en norsk Howard" (s. 75)) om det britiske fængselsvæsen som forbillede for det norske sammen med samtidige bestræbelser for at forbedre sindssygevæsenet i Norge.

Efterfølgende analyseres i kapitel 3 den i 1837 nedsatte straffeanstaltskommission, der, helt i overensstemmelse med den internationalt blomstrende fængselsdiskurs, i sin over 700 sider lange indstilling $i 1841$ foreslog at opføre syv cellefængsler, hvor fangerne skulle afsone i fuldstændig isolation med forbillede i det såkaldte Pennsylvania-system. Stortinget bevilligede 1842 dog kun én anstalt, nemlig Botsfengslet ved Kristiania, 
som "skulle være et menneskelaboratorium for utprøvning af de nye og lovende måter å straffe på” (s. 128). Dette mønsterfængsel stod dog efter en del forhandlinger i parlamentet først færdig i 1851. Derudover vedtoges i 1848 en ledsagende fængselslov, som foreskrev en straffereduktion i forhold til de øvrige anstalter.

Kapitel 4 beskæftiger sig med fuldbyrdelsespraksis i Botsfengslet i dets første årtier. Det viste sig hurtigt, at det nye isolationsfængsel skuffede alle høje forventninger, hvorfor det også forblev landets eneste cellefængsel for fuldbyrdelsen af længere straf. Embedsmændene måtte konstatere en "uophørlig Krigstilstand" (s. 137) mellem fangerne og personalet, en høj tilbagefaldsprocent og psykiske og fysiske skader hos en del af fangerne. Dagligdagen blev derudover reguleret ved hjælp af straf og belønning, som fra 1869 mundede ud i et femtrins-klassesystem, der 1882 blev overtaget af alle norske straffeanstalter, hvorved Botsfengslet endnu en gang fungerede som norsk mønsteranstalt. I overensstemmelse med bogens generelle fokus fremhæver Schaanning den vidensproduktion om fangerne, som blev sat i gang og som fangede de indsatte $i$ et finmasket "vitensnett" (s. 181).

Det centrale kapitel 5 skildrer de "straffepolitiske forskyvninger" i Norge på baggrund af den internationalt opstående kriminologi. Efter et tilbageblik på den strafferetslige diskurs i den såkaldte klassiske skole, der i Norge blev realiseret ved kriminalloven af 1842, skildres opkomsten af kriminologien som den "ny og fremadstormende vitensdisciplin" (s. 217), der både forsøgte at udforske årsagerne til kriminel adfærd og udvikle tiltag til dens forebyggelse og bekæmpelse. Det hører til Schaannings absolutte styrke at skildre, hvordan Norge ved hjælp af et helt arsenal af kriminal- og socialpolitiske love blev til "et foregangsland med hensyn til å ta de nye vitenskapene inn i varmen" (s. 249). Der indførtes med straffeprocessloven (1887) mulighed for at undlade at rejse tiltale, betingede domme (1894), en værgerådslov (1896), en løsgængerlov samt en ny fængselslov, som gav mulighed for prøveløsladelse (begge 1900), og endelig, med den nye straffelov (1902), sikring og forvaring af de utilregnelige og farlige forbrydere. Dette katalog blev i mellemkrigstiden suppleret med udvidet mulighed for at bruge sikring (1929) samt en steriliseringslov (1934). Alle nævnte tiltag resulterede i et mere effektivt og meget differentieret straffesystem, der svækkede koblingen til det konkrete lovbrud og derved også generelt de (potentielle) kriminelles retssikkerhed.

Kapitel 6-8 analyserer, hvordan norske læger og Botsfengslets personale $\mathrm{i}$ hele perioden på baggrund af studier af udenlandsk litteratur og forskningsopholdet $i$ andre lande producerede og udbredte kriminologisk viden om fangerne i Norge 
igennem foredrag, redaktionsarbejde og forskellige udgivelser, samt også påvirkede landets kriminalpolitik. Mens kapitel 6 koncentrerer sig om en række læger, fokuserer kapitel 7 på baggrund af den internationale fængselskongresbevægelse udførligt "på den kriminologisk inspirerte vitensproduksjonen og vitensutøvelsen" (s. 330) i Botsfengslet. Schaannung påviser bl.a. på grundlag af fangeprotokollerne, "at kriminologien sivet inn $i$ fengslet og preget selve fangeforvaltningen" (s. 406) repræsenteret først og fremmest af direktørerne, men også af præsterne og, i mindre grad, lærerne. Det sidste kapitel 8 er slutteligt forbeholdt fængselslægen Johan Scharffenberg, som fremstår som Norges vigtigste kriminolog helt op til slutningen af mellemkrigstiden.

Med rette resumerer Schaanning i sine afsluttende bemærkninger, at den strafferetslige, kriminalpolitiske og kriminologiske virksomhed i Norge var uadskilleligt vævet sammen og centreret omkring Botesfengslet som "uunnværlig laboratorium", selv om dets betydning indenfor det norske straffevæsen bestemt var aftagende. Før 1900 blev viden skabt ved hjælp af straf og belønning, mens straffen efterfølgende blot var en "en integreret del av vitensproduksjonen". Til gengæld havde målet med denne vidensproduktion forskudt sig fra forbedring til "diagnose og etiologi" (464). Mens Schaanning således identificerer århundredeskiftet som en klar cæsur, konstaterer han i sit ud- blik over tiden efter Anden Verdenskrig en videreførelse af den skildrede traditionelle kriminologi helt op til 1970erne.

Schaanning har skrevet en vidende og detaljeret historie om den norske straffetænkning, kriminalpolitik og kriminologi mellem 1800 og 1940 på baggrund af et stort norsk kildemateriale, deriblandt både publikationer og arkivalier, og en del international litteratur - uanset nogle småfejl (f.eks. nævnes der på s. 249f. en ellers ukendt nordisk kriminalistforening i 1893). Det er alene i betragtning af undersøgelsesperioden helt legitimt og velbegrundet, at bogen på den ene side fokuserer på Botsfengslet og på den anden side på lægerne som centrale aktører samt "den medisinske tenkemåten" (s. 275) som den røde tråd i den norske straffepolitik og kriminologi. Selv om bogen således med rette ikke kaldes for en historie om den norske kriminologi, havde man gerne læst en begrebshistorisk udredning af de flittigt brugte og centrale begreber kriminologisk/kriminologi udover en kursoriske bemærkning på s. 217. Schaannings valg af perspektiv fører også til, at kriminologiens sociologiske aspekter samt den strafferetslige diskurs og fængselsdiskursen hovedsageligt analyseres gennem 'kriminalbiologiske briller'. Et udvidet forskningsperspektiv under inddragelse af den voksende udenlandske litteratur, f.eks. om det intensive internationale samarbejde på feltet $\mathrm{i}$ denne periode før kriminologiens (universitære) 
institutionalisering, kunne muligvis nuancere Schaannings indledningsvis formulerede tese, at "den kriminologiske diskursen kolonialiserte de to andre" (s. 12).

Et andet forslag til fremtidig forskning gælder analysen af andre centrale strukturer og aktører udover fængselspersonalet, f.eks. juristerne og de politisk ansvarlige i Norge, som måske kunne forklare "spriket mellom fengselsreformsdiskursen ... og strafferetsdiskursen" (s. 215), der førte til, at Stortinget i 1842 næsten samtidig bevilgede et nyt fængsel og vedtog en straffelov, der $i$ væsentlige punkter stod i direkte modsætning til hinanden. Endnu mere brændende er spørgsmålet, hvordan det lykkedes for Norge så tidligt og på så forholdsvis kort tid at implementere den skildrede perlerække af love mellem 1897 og 1902. Mit gæt ville være, at juristerne, og frem for alt den såkaldte moderne skole i strafferetsvidenskaben med den norske kriminalistforening i spidsen spillede en førende rolle, ligesom det havde været tilfældet $i$ f.eks. Tyskland og Danmark. Dette kompleks berører det grundlæggende spørgsmål om forholdet mellem ny opstående viden(skab), repræsenteret af forskellige vidensudøvere eller eksperter, og (politisk) magt, som formentlig også i Norge ændrede sig gennem tiderne og ikke mindst i efterkrigstiden.

Schaannings studie passer godt ind $i$ et blomstrende internationalt forskningsfelt, og det er synd, at den på grund af sprogbarrieren forment- lig kun vil blive læst $\mathrm{i}$ begrænset omfang. Bogen placerer Norge indenfor den internationale udvikling som et land, der ganske vist ikke var innovativ $i$ udviklingen af nye ideer, men derimod gjorde sig internationalt bemærket som foregangsland med hensyn til dets implementering ved hjælp af love. Ikke mindst ligger bogens store fortjeneste $i$ at demonstrere emneområdets bredde, omfattende både strafferetslige, kriminal-, social- og befolkningspolitiske aspekter, som heller ikke på 471 tætskrevne tekstsider uden fodnoter kan forventes at behandles udtømmende.

\section{Martina Henze}

\section{Opbyggelig og klar oplysning}

Mikekel Thorup (red.) Den skotske oplysning, tekster af Bernard de Mandeville, Adam Smith, David Hume og Adam Ferguson, introduktion ved Jens Erik Kristensen \& Mads P. Sorensen, SLAGMARKs Skyttegravsserie, 267 sider, $198 \mathrm{kr}$.

Bogen introducerer nyttigt til en vigtig idéhistorisk tradition, nemlig den skotske oplysning, hjemhørende, som den fransk og tyske oplysningstækning, i det 18. århundrede. En af hovedrepræsentanterne, David Hume, sondrer, $i$ et essay inkluderet $\mathrm{i}$ bogen, mellem overfladiske og dunkle tænkere (p. 187). Han ser klart de sidste som de mest interessante og sig selv som faldende i den kategori. Dunkle tæn- 